\title{
NLGN4X wt Allele
}

National Cancer Institute

\section{Source}

National Cancer Institute. NLGN4X wt Allele. NCI Thesaurus. Code C75746.

Human NLGN4X wild-type allele is located within Xp22.32-p22.31 and is approximately $339 \mathrm{~kb}$ in length. This allele, which encodes neuroligin 4 , X-linked protein, may be involved in the mediation of synapse function. Mutations in the gene are associated with X-linked autism and Asperger's syndrome. 